\title{
Urgences
}

\section{Sur la Piazza Farnese...}

\section{Rolande Ross}

Numéro 14, août 1986

Corps et jouissances

URI : https://id.erudit.org/iderudit/025263ar

DOI : https://doi.org/10.7202/025263ar

Aller au sommaire du numéro

Éditeur(s)

Urgences

ISSN

0226-9554 (imprimé)

1927-3924 (numérique)

Découvrir la revue

Citer ce document

Ross, R. (1986). Sur la Piazza Farnese... Urgences, (14), 45-47.

https://doi.org/10.7202/025263ar

Ce document est protégé par la loi sur le droit d'auteur. L'utilisation des services d'Érudit (y compris la reproduction) est assujettie à sa politique d'utilisation que vous pouvez consulter en ligne.

https://apropos.erudit.org/fr/usagers/politique-dutilisation/
Cet article est diffusé et préservé par Érudit.

Érudit est un consortium interuniversitaire sans but lucratif composé de l’Université de Montréal, l'Université Laval et l'Université du Québec à Montréal. Il a pour mission la promotion et la valorisation de la recherche. https://www.erudit.org/fr/ 
Rolande Ross 
Sur la Piazza Famese, une odeur de magnolias, de beignes et de pistaches. Et votre clin d'oeil pour arroser le tout. Mais à ce moment précis où votre paupière

rencontre

l'autre,

vous souriez: quelque chose vous échappe qui vous semble dérisoire et à moi, désirable.

Je retoume tout à coup de l'âme en plein

coeur

de l'Italie et cherche dans mes souvenirs ce qu'il faut dire dans ces moments-là.

J'attends que votre sel sèche sur mes doigts pendant que vous remettez le drap sur le lit comme on le fait pour un mort.

Vous signez ainsi ce qui de cette jouissance ne dure pas et buvez du vin pour y revenir.

Demain, il va sans dire que ce sera autre chose.

Le plaisir peut-être ou la mise en page du

désir

dans la marge.

Ou en exergue dans l'échappée du texte qui se remémore, se blanchit, se confond dans les visages et dans les noms.

Il est rare que deux corps partagent le même lieu et jouissent du même souffle. C'est si rare que nous ne parlons que de ça alors que le soleil se couche sur le Trastevere. 
C'est bien ce qui vous semble dérisoire et à moi désirable.

D'où la quête de l'insensé entre nous à marteler la chair dans la pierre ou dans les mots, à polir ici ce qui se texture là.

Et votre corps dérive; vous me racontez une histoire à dormir debout comme seule savez le faire en mots du pays ou d'ailleurs.

Je vous retrouve étendue

sur vos images et vous riez, reprenez de la vie: c'est bien de cela dont je jouis. Quand votre corps parle et qu'il s'étire une cigarette entre les mots, un café entre deux phrases.

Un

moment d'arrêt dans le blanc comme la pointe du désir. C'est ainsi que je suis née et vais

mourir,

confondue au texte

de

l'autre qui est aujourd' hui le vôtre. Confondue à la jouissance de votre corps qui ne sera jamais la mienne.

Je vous regarde refermer les volets et faire nuit sur ce qui nous sépare et je vous jouis à fleur de peau si admirable et insensée. Je n'ai plus rien à raturer ni à rajouter, qu'à déposer ma tête contre votre visage et à mounir doucement de votre

silence. 